\title{
Ethnic rights and the dilemma of extractive development in plurinational Bolivia
}

\section{Rickard Lalander}

To cite this article: Rickard Lalander (2016): Ethnic rights and the dilemma of extractive development in plurinational Bolivia, The International Journal of Human Rights

To link to this article: http://dx.doi.org/10.1080/13642987.2016.1179869

曲 Published online: 06 May 2016.

Submit your article to this journal ¿

Q View related articles $\sqsubset$

View Crossmark data ¿ 


\title{
Ethnic rights and the dilemma of extractive development in plurinational Bolivia
}

\author{
Rickard Lalander* \\ Latin American Studies/Political and Economic Studies, University of Helsinki, Finland; Department \\ of Political Science, Stockholm University, Sweden
}

\begin{abstract}
The Bolivian constitution of 2009 has been classified as one of the most progressive in the world regarding indigenous rights. The indigenous principles of Suma Qamaña/Vivir Bien/Good Living on the harmonious relationship between humans and nature are established in the constitution. Nonetheless, these rights clash with the constitutionally recognised rights of the nation state to extract and commercialise natural resources (mainly hydrocarbons and mining) under the banner of redistributive justice, welfare reforms and the common good, in this study labelled the dilemma of extractive development. The article is based on ethnographic fieldwork and combines a political economy perspective on the extractive dilemma, while similarly examining the tensions between ethnically defined rights in relation to broader human rights in terms of values and norms related to welfare and conditions of living. The ethnic identity is multifaceted in Bolivia. Large segments of the indigenous population prefer to identify in class terms. The class-ethnicity tensions have altered throughout history, according to changing socio-economic, cultural and political settings. A central argument is that, during Evo Morales' presidency, classbased human rights in practice tend to be superior to the ethnically defined rights, as a reflection of the dilemma of extractive development.
\end{abstract}

Keywords: Bolivia; constitutionalism; ethnic rights; extractivism; identity politics; indigeneity; indigenous peoples; resource governance; social rights

\section{Introduction}

[With this constitution] we have left the colonial, republican and neoliberal State in the past. We take on the historic challenge of collectively constructing a Unified Social State of PluriNational Communitarian law, which includes and articulates the goal of advancing toward a democratic, productive, peace-loving and peaceful Bolivia, committed to the integral development and self-determination of the peoples. ${ }^{1}$

The Bolivian constitution of 2009 is undoubtedly among the most radical in the world regarding the incorporation of international human rights criteria and the recognition of specific indigenous rights. ${ }^{2}$ As expressed above in the fragment of the preamble to the constitution, Bolivia is no longer a republic but a plurinational state, which is a direct acknowledgment of the indigenous custom to organise according to distinct ethno-cultural identification within the same nation state. Additionally, the indigenous ethical-

*Email: lalander@yahoo.com 
philosophical conceptualisation of Suma Qamaña/Vivir Bien (live well) on the harmonious relationships among human beings and with nature/the environment has been established as the backbone of the constitution and national development policies. These innovative reforms have been applauded worldwide and enhanced the ethno-ecologist image of Bolivia and the government of Evo Morales Ayma.

A principal endeavour of the government since 2006 is the ambition to decolonise society, the state and the economy, which is also reflected in the constitution. Historically, the Bolivian political economy had excluded the indigenous population. Mining and extractive capitalism and imperialism based on exploitation of the indigenous peoples as labour force have characterised the Bolivian political economy since colonial times. ${ }^{3}$ The 2009 constitution strengthened the position and role of the state in the economy, as a response to the discontent with neoliberal global capitalism.

The Morales government, which together with Venezuela and Ecuador has been in the forefront of what has been labeled twenty-first century socialism, has repeatedly emphasised that the state should achieve control of extractive industries in order to fund welfare policies and to achieve economic development. Several scholars have debated the advancements of Bolivia's (and Ecuador's) recent political orientation in terms of a post-neoliberal project or progressive neo-extractivism. ${ }^{4}$

Not only indigenous human rights were strengthened in the new constitution and secondary legislation in Evo Morales' time, but also broader social rights: the right to decent living conditions and well-being, instrumentalised through targeted social programmes and other policies aimed at redistributive justice, what is occasionally referred to as classdefined rights in this study.

Regarding the state control of vital industries - mainly hydrocarbons, agro-business and mining - the constitution declares the industrialisation and commercialisation of natural resources to be a key priority of the state, though taking into consideration the rights of indigenous peoples and provided that revenues should be directed at the common good (articles 319 and 355), ${ }^{5}$ as will be further discussed in due course.

The aim of this article is to analytically examine the complex liaisons between ethnic and broader social (class-defined) rights amidst the Bolivian political economy of resource governance. The article consequently adds to the debates on contentious resource governance and the relationship, contradictions and tensions between class and ethnicity amid Bolivian identity politics and the question of indigeneity. ${ }^{6}$ An essential claim is that class-based human rights in practice tend to outplay ethnically defined rights, due to an extractive development dilemma.

The dilemma of state authorities is, consequently, to be able to deliver welfare for all, which requires economic resources. With the public control of strategic industries, the redistribution of wealth through extraction can be achieved; that is, provision of classdefined rights. The rights of indigenous peoples and of the environment are affected in situations where natural resources are extracted in indigenous territories. This follows the logics that have characterised extractive projects around the globe, wherein economy almost always outplays ethnic and conservational rights. Shorter-term politico-electoral and economic realities tend to create social pressure that the state perceives as more urgent than the conservation of the environment and the protection of indigenous communities. In a previous study the metaphor of a straitjacket was used to discuss this unsolvable equation, referring to ethnic and environmental rights in relation to the ambitions of progressive governments to use extractive incomes for welfare reforms, ${ }^{7}$ that is, more class-based concerns.

On the one hand, the complex identity politics of Bolivian indigeneity are examined. On the other hand, the extractive dilemma of the Bolivian government is problematised, 
particularly regarding the discourse and moral justification amidst the implementation of extractive politics on behalf of state authorities and how these discourses and justifications relate to the identitarian elements of class and/or ethnicity. The study likewise considers how these relationships are perceived at grassroots or intermediary socio-political levels, that is, by indigenous spokespersons.

While discussing Bolivian identity politics amidst recent extractive development projects, an additional identitarian element cannot be evaded; namely, the ecologist trait within indigenous identity. The environmental dimension is central in recent contentious politics around extractive projects. While ethnic/indigenous rights evidently are separated from the rights of nature/the environment, they frequently coincide in concrete extractive settings. Therefore, the environmental or ecologist trait of actors and interests will in the future at times be incorporated in the ethnic identity.

As highlighted in a previous article in this journal, international institutions and treaties, such as ILO (International Labor Organization) Convention 169 of 1989 and the UNDRIP (United Nations Declaration of the Rights of Indigenous Peoples) of 2007 may be powerful, albeit symbolic tools for indigenous struggle worldwide. Nonetheless, regarding article 3 of UNDRIP on the 'exercise of indigenous peoples' foundational right to self-determination', the fulfillment of these rights depends on specific domestic politics and laws. ${ }^{8}$

However, neither a progressive legal framework, nor the ratification of international human rights standards concerning indigenous rights can in practice guarantee that these rights are always prioritised. There are contradictions in the constitution as well as in the national development plan, creating clashes between ethnic rights and social welfare goals (class-defined rights). As elsewhere in the continent, the (de jure) rights on paper do not necessarily correspond to the (de facto) rights in practice. ${ }^{9}$

Methodologically, the study draws on ethnographic fieldwork undertaken in Bolivia between 2010 and 2015; hundreds of semi-structured interviews have been realised, although only a selection of these will be mentioned. The ethnographic material is complemented with critical reading of previous scholarly work and legal documents. For the sake of the argument it will be necessary to simplify matters a bit regarding the tensions between ethnicity and class among the actors. In order to see more clearly the particularities of each process or identitarian component, a relative simplification is accordingly essential.

After the contextualisation above, the layout of the text is as follows. First, a concise background of the Bolivian indigenous movement struggle is offered, mainly from 1952 onwards and particularly emphasising the politicisation of ethnic identity and the essential tensions between class and ethnicity. Thereafter, the Vivir Bien philosophy and the contradictory nature of the 2009 constitution are examined, particularly those articles that reflect the values and rights of class and ethnicity and the extractive rights of the state. The Law of Mother Earth and the ecologist traits of the indigenous peoples are then briefly scrutinised. Next, the most emblematic case of ethno-ecologist resistance against extractive developmentalist policies is analysed: the TIPNIS conflict. The TIPNIS case illustrates the contradiction between indigenous rights claims and state practices. Subsequently, before closing the article with a few pertinent conclusions, indigeneity and the extractive development dilemma are further problematised through the analysis of distinctive positions of involved actors.

\section{Bolivian indigeneity and politicisation of ethnicity in retrospective}

In different parts of Latin America, most remarkably in Mexico and Peru, the Indigenismo ideology spread during the first half of the twentieth century and was a strategy to deal with 
the 'Indian problem'. Non-indigenous intellectuals, priests and politicians advocated for the improvement of the social conditions of the indigenous populations, albeit typically with a paternalistic and clientelistic style and as a component of nation building based on mestizaje (miscegenation). For instance, historian Marc Becker concludes that: 'Indigenismo was always a construction of the dominant culture, particularly that of elite intellectual mestizos who used Indigenous issues to advance their own political agendas. ${ }^{10}$

In Bolivia, Indigenismo was articulated already in the 1920s in the attempts to integrate indigenous and mestizo workers, accordingly realigning the relationship between the nonindigenous working class and the indigenous peoples. ${ }^{11}$ The most persistent expression of Bolivian Indigenismo, however, came with the National Revolution of 1952 and the Agrarian Reform of 1953, directed by the MNR party (Movimiento Nacionalista Revolucionario/ Revolutionary Nationalist Movement). Until then, the native populations in both the highlands and lowlands identified precisely as Indians (Indios), but were thereafter redefined as peasants/campesinos.

The 1952 revolution thus brought a cultural 'peasantification' of the indigenous communities and cultural practices, and the traditional sociopolitical and organisational structures were dissolved. The decree of the Agrarian Reform of 1953 also signified that all direct mentions of 'Indian peoples', Aymara, Quechua, etc. were erased. ${ }^{12}$ In retrospect, Quechua intellectual and educator Leonel Cerruto exposes the following:

1952 is a rupture, because it wasn't the Indigenous movement that established the fracture or the individual land property. It came as a current of the Left, copied from Mexico. Of course, the Indigenismo [and its slogans of] land for the peasants, land for those who work it. So, the 'peasantification' (campecinización) begins at that moment, also for the indigenous Bolivians. However, they do not finish being neither Indigenous nor native. No. This problem persists until today. ${ }^{13}$

Already in the 1960s and 1970s radical indigenous intellectual organisations reacted to this cultural usurpation and homogenisation. Young urbanised indigenous students gathered around the Quechua-Aymara writer and intellectual Fausto Reinaga who wrote and spoke of the importance of the ethnic and cultural roots of the indigenous peoples. Reinaga rejected the 'peasantised' identity and endorsed a return to indigeneity. Jesuit anthropologist Xavier Albó summarises the meetings around Reinaga: 'We were reduced

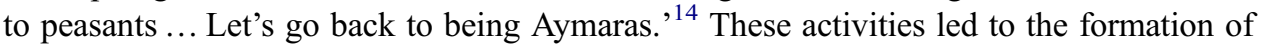
two parallel movements: the Katarismo and Indianismo.

Historian Pedro Portugal Mollinedo militated in the Indianismo movement and he recalls that whereas Indianismo accentuated the cultural, racial and national aspects of the indigenous peoples, Katarismo concentrated on economic and social class dimensions of struggle. ${ }^{15}$ Both of these movements - at times merged and occasionally opposing each other - challenged the dominant peasant class-intensive rhetoric of the period and onwards originated in different political organisations and discourses. The indianistas organised early into their own political parties, in 1960 as PAN (Partido de Acción Nacional), later in 1968 as Movimiento Nacional Tupak Katari and in 1978 as Movimiento Indio Tupak Katari/MITKA. A leading Aymara indianista was Constantino Lima. In his words: 'As Indians they subjugated us, as Indians we will liberate ourselves. ${ }^{16}$

The maximum emblematic historical figure of both Indianismo and Katarismo was Túpak Katari who, before being executed by the Spaniards, led an indigenous rebellion in the early 1780 s together with his mistress Bartolina Sisa. The Kataristas were in comparison more successful in organised peasant-indigenous struggle with their Movimiento 
Revolucionario Tupak Katari/MRTK party. In the 1990s, an armed katarista guerrilla movement operated: the Tupak Katari Guerrilla Army/Ejército Guerrillero Tupak Katari, which included prominent names such as Felipe Quispe (who later would become president of the indigenous-peasant union CSUTCB (Confederación Sindical Única de Trabajadores Campesinos de Bolivia)) and the current Bolivian vice-president Álvaro García Linera. ${ }^{17}$

The later Leftist political turn with Evo Morales as president is the outcome of decades of indigenous social movements' struggles against neoliberal politics, which dominated as the economic doctrine since 1985. Indigenous movement struggle is per se a proposal of systemic change and a rejection of global capitalism, imperialism and oppression along the lines of ethnicity and class.

A crossroads regarding the indigenous struggle occurred in 1990, when the lowland indigenous confederation CIDOB (Confederation of Bolivian Indigenous Peoples) organised a great March for Territory and Dignity from Trinidad in the lowlands to La Paz. The indigenous peoples had struggled for decades for deepened autonomy and dignity; since 1989 this was further triggered by ILO Convention 169. Also, highland indigenous organisations intensified pressure during the period and, despite the neoliberal context, the 1990s saw several legal recognitions of the ethnically defined grievances, such as the Law of Popular Participation/LPP of 1994 and the approval of Native Communal Lands/ TCOs (Tierras Comunitarias de Origen). The Bolivian ratification of ILO Convention 169 in 1991 was the outcome of the CIDOB march in 1990. However, the concrete implementation of Convention 169 and the more comprehensive right to prior consultations on hydrocarbon activities in Bolivia were deferred until 2007, that is, after the presidential inauguration of Evo Morales. ${ }^{18}$

The period until 2003 was characterised by anti-neoliberal protest activities - road blockings, street manifestations, strikes, etc. - and indigenous organisations strengthened their central role. In the awakening of the new millennium, the growing movement around Morales was at the epicentre of several resource conflicts, most decisively during the so-called 'water war' (protests against the privatisation of water) in Cochabamba in 2000 and the 'gas war' (against the export of gas to the United States via Chile) in El Alto-La Paz in 2003, which concluded with the resignation of neoliberal President Gonzalo Sánchez de Lozada. ${ }^{19}$

\section{Now the indigenous social movements are government}

In December 2005, the leader of the coca-growing peasants, Evo Morales, was elected president of Bolivia, the first indigenous president ever of Latin America, representing the political party/movement MAS-IPSP (Movimiento Al Socialismo - Instrumento Político por la Soberanía de los Pueblos/Movement Towards Socialism - Political Instrument for the Sovereignty of the Peoples), which was a creation of the principal Bolivian indigenous-peasant social movements. The election of Morales can be viewed as the culmination of a protest cycle against exclusionary political and economic structures and also as recognition of previously disregarded citizens and collectives (mainly the indigenous and the poor).

Undoubtedly, a relative dignification of indigenous Bolivians has taken place during the Morales era. While racism and discrimination of indigenous citizens still exist as fundamental ills of Bolivian society, being indigenous is nonetheless not constantly an obstacle, compared to the pre-Evo period. Under the banner of decolonisation, a gradual social transformation has occurred, with improvements concerning ethnically defined recognition. A common joke during the first years of Morales' presidency was that before going to a job interview, the best thing to do was to first dress up in a poncho and/or other ethnic symbols. 
For some scholars, a redefinition of peasant-indigenous citizenship and of the connotation of the Bolivian nation took place. This was achieved through the combined struggle of the indigenous-peasant base organisations and the political-electoral instrument (MASIPSP, onwards referred to as MAS) that, via the channels of representative democracy, succeeded in occupying the state. ${ }^{20}$

Some words are needed regarding the principal organisations of the indigenous movement. These have different profiles concerning class and/or ethnicity. The already mentioned lowland confederation, CIDOB, is traditionally associated with an ethnic profile, as reflected also in its name (Confederation of Bolivian Indigenous Peoples). The second, more indigenous of the organisations, or perhaps even native ${ }^{21}$ (originario), ${ }^{22}$ is the highland Aymara and Quechua Council CONAMAQ (Consejo Nacional de Ayllus y Markas del Qullasuyu). The remaining four organisations are in comparison more classintensive; the Bolivian Workers Central/COB (Central Obrera Boliviana), the already mentioned peasant union CSUTCB, the Bartolina Sisa National Confederation of Peasant, Indigenous, and Native Women of Bolivia/CNMCIOB-BS (Confederación Nacional de Mujeres Campesinas Indigenas Originarias de Bolivia Bartolina Sisa), and the Unionist Confederation of Intercultural Communities of Bolivia/CSCIB (Confederación Sindical de Comunidades Interculturales de Bolivia). ${ }^{23}$ The backbone of this last organisation the CSCIB - is the coca-growing migrants, originally from the highlands, but for many years established also in the lowlands. These four organisations support the MAS government, whereas CONAMAQ and CIDOB have divided. ${ }^{24}$ Nonetheless, all six organisations participated in the processes of rewriting the constitution.

Even though I argue that class and ethnicity are complexly merged in all organisations mentioned here - and that the differences frequently tend to be more semantic - it is interesting that some authors make a distinction between indigenous and native and classify CONAMAQ as native and CIDOB as indigenous. The Bartolina Sisa is labelled peasant/class-intensive, but includes both indigenous and native in its name. ${ }^{25}$ The CSUTCB was born out of the Katarista movement, albeit backed up by the Catholic Church, NGOs (non-governmental organisations) and leftist political parties. ${ }^{26}$ In one of its first official documents, the political thesis of the confederation in 1979, the organisational identity is expressed as 'Aymara, Quechua, Campa, Chapaco, Chiquitano, Moxo, Tupiguaraní and other peasants, ${ }^{27}$ that is, both peasant and indigenous. According to its current organisational statutes (art.3.1), the CSUTCB is the:

... maximal natural and historical organization that represents the totality of Indigenous-nativepeasant nations and peoples of the Plurinational State, the setting of historical struggles of the indigenous-native-peasant movements in pursuit of the liberation of the colonial and republican state. $^{28}$

As early as 1994, the CSUTCB agreed upon the strategy to form a 'political instrument', specifically to be able to 'create our own state, with our own constitution, in which indigenous nations can produce their own state' and this meeting can be considered the embryo of the route towards the constitution of $2009 .{ }^{29}$

\section{Vivir Bien, ethnic rights and the extractive dilemma in the constitution of 2009}

The indigenous ethical-philosophical principles of Suma Qamaña (Aymara) - in Spanish translated to Vivir Bien (Live Well) - are incorporated as the backbone of the new constitution and the national development plans in Evo Morales' era. As often voiced by Morales 
and Bolivian Foreign Minister David Choquehuanca (who like Morales is Aymara), the idea is to live 'well' and not 'better' (at the cost of others), that is, not strive for material and economic accumulation, to increase 'living conditions' on a personal level, better than the neighbours, etc. Interestingly, the more ecologically concerned faction of the government - the Pachamamistas - can be traced back to a group within the Indianismo movement decades earlier. Incidentally, Choquehuanca has publically identified as Indianista. ${ }^{30}$

Advocates of Suma Qamaña suggest that development/progress as most people understand it is unnecessary. Individual as well as national economic 'progress' and 'wellbeing' regarding material belongings and capital accumulation and so forth, according to traditional notions of development, should be compared with a life in harmony with the environment and other human beings, without the burdens of global capitalism on nations and of consumptionism on individuals and collectives. Academics, social movement activists and politicians in Bolivia, Ecuador and elsewhere frequently use the Vivir Bien concept, both as a critique of development (understood as progress/economic growth) and as a principle of harmonious and ecologically sustainable life. ${ }^{31}$

Now, for a better comprehension of the legal setting and the complexities amidst the dilemma of extractive development, the ethnic-indigenous as well as broader social rights, and also the 'extractive developmentalist' rights of the state, it is of great importance to examine some crucial parts of the 2009 constitution.

In its preamble, the constitution declares that Bolivia is no longer a republic but a plurinational state. The plurinational character of the 'refounded' Bolivia embraces several dimensions. The first is related to decolonisation and the historical-symbolic recognition of legal pluralism, indigenous autonomies in parallel to the traditional politico-territorial division of the state, as well as a broader reconfiguration of the political society based on indigenous participation. Another element is precisely that of the plurality of nations, which promotes the rights of different indigenous nations to articulate political demands and administer justice within the Bolivian nation. ${ }^{32}$

A novelty of the constitutional text relates to the central identitarian concepts of this study. In each citing of the ethnically defined peoples, indigenous is grouped together with peasants/campesinos and natives/originarios: indigena-campesino-originario, that is, as indigenous-peasant-native peoples. This innovation will be discussed later.

The indigenous identity and specific indigenous rights are specified in articles 30-32; for instance the right to self-determination and territoriality. Regarding who is to be classified as indigenous, the first part of article 30 declares:

[They are] the rural native indigenous people and nationality consisting of every human collective that shares a cultural identity, language, historic tradition, institutions, territory and world view, whose existence predates the Spanish colonial invasion.

In the same article, the rights to prior consultation and free, prior, informed consent/FPIC of the indigenous peoples are mentioned. The right to prior consultation and FPIC of the affected indigenous peoples before extractive activities take place in their territories is a crucial component of the dilemma of extractive development. Even if this legal and rights-based mechanism has been practiced more frequently in Bolivia than in the majority of neighbouring Latin American countries, numerous shortcomings have characterised these procedures, such as insufficient decision-power and information of the involved population, irregularities and lack of transparency as concerns compensation payments. ${ }^{33}$

Another important recognition of indigenous rights is that of indigenous native peasant autonomy/Autonomía Indigena Originaria Campesina (articles 289-296), likewise 
accompanied by secondary legislation in 2009. Notwithstanding, as argued by Canessa, the government resisted the ambitions of numerous indigenous communities that tried to achieve the status of autonomous indigenous municipalities via a referendum. The argument of the government was principally that 'the state was already indigenous' and the unity of the indigenous peoples was thus at stake should they to go ahead with the procedure. $^{34}$

The protection of natural parks and indigenous territories is pronounced in article 385, whereas, the territorial rights of indigenous peoples are expressed in articles 394-395:

The State recognizes, protects and guarantees communitarian or collective property, which includes rural native Indigenous territory, native, intercultural communities and rural communities. Collective property is indivisible, may not be subject to prescription or attachment, is inalienable and irreversible, and it is not subject to agrarian property taxes. Communities can be owners, recognizing the complementary character of collective and individual rights, respecting the territorial unity in common.

Nonetheless, in parallel to the collective indigenous rights, numerous individual and universal rights are expressed (some of which evidently are rooted in indigenous culture), such as in article 8:

The State is based on the values of unity, equality, inclusion, dignity, liberty, solidarity, reciprocity, respect, interdependence, harmony, transparency, equilibrium, equality of opportunity, social and gender equality in participation, common welfare, responsibility, social justice, distribution and redistribution of the social wealth and assets for wellbeing.

Broadly speaking, throughout the constitution there are references to the central objectives of poverty reduction, welfare provision, economic development and environmental protection (e.g. article 312). Moreover, articles 306 and 313 emphasise that the overarching ambition of Bolivian economic policies is to overcome poverty and social/economic exclusion [class-defined rights]; consequently the following sub-goals are identified:

1. The generation of social wealth within the framework of respect for individual rights, as well as the rights of the peoples and nations.

2. The fair production, distribution and redistribution of wealth and economic surplus.

3. The reduction of inequality of access to productive resources.

However, as mentioned in the introduction, the same constitution equally expresses the rights of the state to explore the natural resources of the soil, as pronounced in articles 319 and (below) 355, which also indicates the destination of the incomes derived from these activities:

I. The industrialization and sale of natural resources shall be a priority of the State.

II. The profits obtained from the exploitation and sale of the natural resources shall be distributed and reinvested to promote economic diversification in the different territorial levels of the State. The law shall approve the percentage of profits to be distributed.

III. The processes of industrialization shall be carried out with preference given to the place of origin of the production, and conditions shall be created which favor competitiveness in the internal and international market. 
Clearly, prevailing economic and political interests conflict with indigenous-territorial and environmental rights. This enigma - reinforced rights and the maintenance of resource extraction reliance - is clearly expressed in the constitution. National authorities justify the persistent extraction with the necessity to achieve distributive justice, that is, a diminution of poverty and the provision of welfare for all, especially the marginalised sectors. This approach, with the partial sacrifice of the specific rights of the environment/nature and indigenous peoples to achieve social welfare is sometimes labelled progressive neo-extractivism. ${ }^{35}$

\section{The Law of Mother Earth and the ecologist traits of the indigenous peoples}

Reconnecting to Vivir Bien and the ethno-environmental profile of Bolivia, in 2010 the Law of Mother Earth was established. The law embraces, among others, the rights to the protection of the integrity of life and natural processes, the continuation of vital life cycles and processes free from human alteration and to not be affected by mega-infrastructure and development projects that disturb the balance of ecosystems and local communities. In 2012 the law was upgraded by the National Legislative Assembly as the Framework Law of Mother Earth and Integral Development to Live Well/ Ley Marco de la Madre Tierra y Desarrollo Integral para Vivir Bien. ${ }^{36}$ The framework character of the law implies that it is superior to other laws. For instance, the laws of mining, hydrocarbons, water, etc. should correspond to the contents of the framework law. The second part of the law should be emphasised, namely the integral development which refers to the objectives of Vivir Bien beyond merely environmental concerns and the proper rights of nature. Even if the environmental concerns are fundamental, the integral development component adds a more pragmatic dimension in considering human needs and rights as well. ${ }^{37}$

Nicole Fabricant reasonably criticises the 'indigeneity' component of the discourses based on ecologism and the sustainable ways of living by the indigenous population, as these are based on rural populations, with a close relationship to the territory. She therefore questions the relevance of these logics for the large urban indigenous population. Likewise, Fabricant is sceptical vis-à-vis the Vivir Bien alternative provided to confront the climate crisis. $^{38}$

A few words on the possible ecologist trait of the indigenous peoples are required. The notion of the 'ecologically noble native' has been used in discourses both by the Morales government and by oppositional indigenous activists. However, whether this identitarian feature of the indigenous is natural, intrinsic or automatic might be questioned. For some scholars, the 'ecological Indian' is one of the oldest myths of anthropology ${ }^{39}$; or it might be understood as partly constructed identities, that is, through the strategic fusion of ecologist and indigenous discourses at local and transnational levels. As Astrid Ulloa convincingly argues, indigenous organisations have been successful in being perceived around the globe as the prime defenders of the interests of Mother Earth, as frequently is observable at international climate summits. ${ }^{40}$

This is not to claim that the environmental concern of the indigenous organisations should not be taken as a serious grievance. However, one should not take completely for granted that this ecologist concern is automatic. Indigenous peoples are not a homogenous group and other identity-based concerns might be superior in specific situations, such as questions of poverty and ethnic discrimination.

Indigenous intellectual NGO activists Edwin Armata Balcazar and Walter Limache Orellana clarify that ecologism may not generally constitute the superior element of indigenous identity, but concerned indigenous peoples are inclined to react when extractive projects threaten their traditional livelihoods. ${ }^{41}$ 


\section{The TIPNIS conflict}

The national park and indigenous territory of TIPNIS (Territorio Indigena y Parque Nacional Isiboro Secure) is the home of, among others, the Mojeño-Ignaciano, Yuracaré and Chimán indigenous peoples and is similarly a territory of rich biodiversity. Since 2011, TIPNIS has been the most emblematic Bolivian case of contentious politics between the state and indigenous and environmental activists. Between 15 August and 19 October 2011, a huge number of indigenous and other activists marched for 65 days from the Bolivian lowlands to the capital protesting against a highway construction project through the protected area and indigenous territory.

The population living in TIPNIS is polarised regarding the highway. There are groups of people in TIPNIS that support the highway, such as the migrating coca workers that see economic opportunities with the improved infrastructure. Throughout the conflict, the government justified the TIPNIS project with arguments related to social welfare, such as the promotion of health, education and infrastructure for isolated indigenous groups.

The 602-kilometre highway project would connect the lowland Beni department with highland Cochabamba and was a key project of Latin American integration by the new progressive governments following the commodity export strategy. Brazil was deeply involved in supporting the road so as to facilitate access to Pacific markets. The Brazilian Development Bank/BNDES financed the highway project and the Brazilian construction company OAS was contracted, which together with the interests of oil company Petrobras underscore the shifting continental geopolitical order. The Initiative for the Integration of the Regional Infrastructure of South America (IIRSA) is a strategic project of regional integration for the common good (welfare reforms), which is the technical project of the South American Council of Infrastructure and Planning (COSIPLAN) of UNASUR (Union of South American Nations). However, Vice-President Álvaro García Linera categorically denounces the alleged relationship between IIRSA and the TIPNIS highway. ${ }^{42}$

The protesters - led by the territorial organisation Subcentral TIPNIS and the CIDOB and CONAMAQ indigenous confederations - presented a list of 16 demands concerning respect for the territory as well as other social, economic and cultural concerns. After a few violent clashes between police forces and the marchers, President Morales agreed to all demands presented. Nonetheless, after a few months the highway project was reinitiated, despite heavy resistance and international media and academic coverage. ${ }^{43}$

Celso Padilla is leader of the Assembly of the Guaraní People/APG. During the march he declared that:

We want to tell the Government that 'this' is the Plurinational State. Here we are the 34 indigenous groups. We want to tell the President Evo Morales that the State is built with these people. He should not concentrate the power only on CSUTCB, the 'Bartolinas' and the intercultural communities. We, these indigenous groups took him to power. Why he forgets so quickly? $^{44}$

It is revealing that Padilla directly refers to the 'factionalism' of the indigenous movements and mentions the three most devoted supporters of the Morales government (CSUTCB, the Bartolinas and the Interculturals, that is, the more class-intensive organisations, in comparison with the ethnic profile of CIDOB to which the APG is associated).

The TIPNIS conflict unexpectedly ended - at least momentarily - in a rather peculiar way. During fieldwork in Bolivia in January 2014, the local academics' and activists' surprise was apparent regarding announcements (as quoted in local mass media on 4 January) by Vice-President García Linera vis-à-vis the destiny of the TIPNIS highway in June 2013 
at a conference in Argentina - seven months earlier. García Linera acknowledged several mistakes committed by the government concerning the construction project and communication with affected indigenous groups (among others regarding the right to free, prior, informed consultation). He stressed that the highway will be indispensable but that it had to be postponed 20,50 or 100 years and should be cautiously realised with regard to environmental protection. ${ }^{45}$ During interviews in La Paz in January and February 2014, several government spokespersons confirmed that the highway construction was cancelled 'because the vice-president said so'.

Yet, this position of the government was rapidly altered after the presidential elections of October 2014, when Morales was re-elected by a landslide. So, the government decided once again to move onwards with the TIPNIS highway. Moreover, on 20 May 2015, Morales drafted and established a presidential decree that profoundly altered the rules of the political game in the protected areas, some of which are also indigenous territories. Morales reasoned that the national parks had been established by elite groups in Bolivia and beyond as a kind of standby supply of natural resources. State authorities plan to initiate oil drilling in eight of the existing 22 protected areas of the nation. ${ }^{46}$ According to superior decree 2.366, the hydrocarbon resources in all parts of the nation could be extracted and commercialised for the common good (social welfare/poverty reduction). ${ }^{47}$

Moreover, Vice-President García Linera declared that a legal amendment of the statute on the intangibility of TIPNIS should be realised, ${ }^{48}$ which was one of the central accomplishments of the 2011 indigenous march for TIPNIS. Based on public statistics and according to calculations by CEDIB (Bolivia's Documentation and Information Centre) oil and gas concessions today overlap 11 of the 22 Bolivian protected areas. In TIPNIS, $35 \%$ of the territory is assumed to be open for oil and gas extraction according to these figures. ${ }^{49}$ Morales presents other statistics concerning the proportions affected by extractivism. According to the president, the extractivism will affect only $0.0008 \%$ (205 hectares) of the territory of seven protected areas (in total 3.9 million hectares, each area with an average size of 560,000 hectares). Regarding the right of the affected population to prior, free and informed consultation, heavily debated throughout the TIPNIS conflicts, Morales has repeatedly expressed that he considers this procedure to be a waste of time and money, but that this right of the peoples should be respected. ${ }^{50}$

In early October 2015, the Ministry of Energy and Hydrocarbons publically announced that it had the support of around 50 affected indigenous communities (mostly Guaraníes) in the departments of Tarija, Santa Cruz and Chuquisaca, concerning the exploitation of hydrocarbons in the protected areas. The Minister of Energy and Hydrocarbons, Luis Alberto Sánchez, referred to letters from the concerned indigenous groups, which expressed their backing of development plans in their regions. As they argued, they wished to 'have the same opportunities as elsewhere as regards, schools, hospitals and roads' ${ }^{51}$

Bolivia's Minister of Planning, sociologist René Orellana, reflects on the TIPNIS conflict and existing ethical and economic challenges:

Bolivia needs that highway. And we need to take advantage of the existing hydrocarbon resources. Why not? We have to do it, although respecting the limits of regeneration and searching for the best technological conditions. So: why not? Sometimes I don't understand how certain actors say: 'We can't do that; the rest of Bolivia should not be benefitted by those resources.' That's an egoistic position. We need the complementarity of rights. All rights are exclusive; the economic, social and cultural rights, the rights of the poor and of all citizens are superior. ${ }^{52}$ 
Summing up, as reflected above, the TIPNIS case can be viewed as an illustration of the superiority of class-defined rights vis-à-vis ethnic rights, for instance when the justification of the government is exposed in discourses.

\section{Indigeneity and the dilemma of extractive development}

In almost ten years of the cultural and democratic revolution, Bolivia has positioned itself as an international reference. Initiated in the social movements, our own economic, social and communitarian model is independently established. We have recovered our natural resources that will allow us to redistribute the revenues, benefiting all Bolivians (Evo Morales Ayma, Public Discourse, August 2015). ${ }^{53}$

The capitalist logics of accumulation are still central traits of the Bolivian political economy, which has been criticised by many activists and scholars that were hoping to witness the progress of an anti-capitalist/post-capitalist project in the country. ${ }^{54}$ However, the Morales administration has since the beginning explicitly communicated that the state should attain control of extractive industries so as to finance welfare reforms and to achieve economic development. Moreover, as argued by Almut SchillingVacaflor, the Morales government realised radical legal reforms regarding both human rights and environmental principles within the hydrocarbon sector. These improvements, including the acknowledgment of rights in the 2009 constitution, were the outcomes of decades of popular struggle, principally by lowland indigenous peoples. ${ }^{55}$

Evidently, the debates on indigeneity and the rights of indigenous peoples as expressed, for instance, by NGOs and the United Nations, might function better in contexts of nation states in which the indigenous peoples are a minority. In Bolivia - since 2006 sometimes categorised as an 'indigenous state' - the indigenous peoples constitute the majority. The Bolivian case displays a series of complexities and contradictions regarding claims of indigenous rights and the meaning of indigeneity. ${ }^{56}$ By the same token, the indigeneity discourse has strategically been used both by government and oppositional activists. $^{57}$

During interviews in the Amazon (Beni department), I was privileged to discuss the territoriality element as the fundamental criteria of indigeneity (referred to in article 30 of the constitution) with a Mosetén leader and a non-indigenous activist. Both expressed a rather fundamentalist definition of territoriality as a superior criterion of indigeneity, and, following that logic, neither urban nor migrating Bolivians of indigenous heritage would qualify as native-indigenous. For the same reason they argued that the only 'pure' native-indigenous organisations would be CONAMAQ and CIDOB. ${ }^{58}$

Quechua educator Leonel Cerruto does not agree. He claims that also urban and migrating indigenous individuals and collectives fulfil the criteria of indigeneity, as also the CSUTCB, the Bartolinas and the intercultural organisations. In the first place, he argues, the indigenous peoples have always been mobile; therefore it is frequently complicated to define the precise native origin of the ethnic group. Moreover, in reference to the constitution and the internal quandaries of the broader indigenous movement, he reflects:

Indigenous-native-peasant without commas enters the constitution as one word in order not to cause fragmentation or division between us, since indigenous, natives as well as peasants deal with territoriality. Our principle has always been land and territory, i.e. both things: land and territory as principles of life. In that way we have been able to rearticulate, but still we have this false vision of the peasant not being indigenous. The only thing that brings us is division, when we really need to unify. ${ }^{59}$ 
In a previous conversation of early 2011, the CSUTCB leader Damián Condori articulated the following regarding identification in terms of class and/or ethnicity (in relation to the formulations in the new constitution):

Yes, we are generally getting used to refer to ourselves as indigenous-natives-peasants. That is, I am not just a peasant any longer. We are peasants, indigenous and natives. Well, we are the majority. Almost $65 \%$ of the population identify as indigenous, natives and/or peasants. And peasant is the most common identity in Bolivia, and this is due to the presence of the CSUTCB in the nine departments. We have executives in the nine departmental federations, whereas the CONAMAQ - who identifies as natives - and was founded only in 1998, is merely marginally important in some places, such as Oruro, parts of La Paz and Potosí. ${ }^{60}$

Anders Burman provides an interesting observation on fluctuating ethnic identities. Earlier highland indigenous peoples identified as 'natives' and referred to the lowland peoples as indigenous. Burman recalls his meetings with CONAMAQ authorities, that in 2001 were perplexed when being labelled 'indigenous/indigena', since the indigenous - according to them - were the lowland peoples, whereas the highland Aymara and Quechua identified as native. In 2011, during the TIPNIS protests, this cultural-semantic identification has altered and CONAMAQ spokespersons now identified and marched as 'indigenous', that is, identifying with a broader struggle, involving also lowland indigenous peoples. ${ }^{61}$ The strategic indigeneity may thus evolve in different directions, either through the "ethnification' of previously class-intensive actors, or, as this case with CONAMAQ, going from native to indigenous.

The indigenous and class-defined discourse of Evo Morales and his government is pronounced and directed at different levels: the domestic and global spheres respectively. Being of Aymara origin, the ethnic identity of the president is extremely important in terms of symbolic ethnic capital. Even though he is first and foremost a peasant unionist and leader of the coca growers, his indigenous identity, albeit merged with classism, is essential in both domestic and internationally targeted speeches.

Nonetheless, regarding the reinforced position of indigeneity in the updated form of citizenship - particularly in comparison with the earlier recognition of indigenous peoples as peasants as a result of the 1952 Agrarian revolution - it is indispensable to provide a broader picture when examining the indigeneity within the political project of the Morales administration. Evo Morales has indeed been portrayed as a climate hero around the world, leaning on discourses based on indigenous values and the worldview of Vivir Bien (Suma Qamaña) as options for responding to both global capitalism and the climate crisis. But, this discourse is applied mostly at a global level, whereas the domestic speeches of Morales deal more with development economics and fair distribution of resources, that is, policies and rights defined by class and social justice. ${ }^{62}$

Jorge Viaña Uzieda is currently the head of a government institution on the issue of indigenous autonomy. Regarding the challenges of political, social, economic and ecological transformation, he espouses the following:

I do not think that Bolivia will resolve the dilemma between development and preservation. That is, the priority of what has been labeled development until now, or less devastating alternatives to development, has been opened and suggested, although as a dilemma, as a question to be resolved ... They have to try to harmonize the relationship between certain necessity to defend and safeguard the environment and the pendant undeniable assignment to create conditions of welfare for the population. And, well, that implies extractivism. Let's be frank, from where will we take the resources? You have to generate surplus and redistribute it. So, the dilemma is planted. ${ }^{63}$ 
The aim was consequently neither to abandon the matrix of capitalist development, nor to entirely end the pollution of nature through extractivism or to always respect the indigenous territories, but to establish the dilemma and propose the Vivir Bien as an alternative to the world. The relative superiority of welfare policies vis-à-vis environmental conservation and (indirectly) indigenous territorial rights is similarly expressed in the quotation.

The government generally applies a pragmatic approach towards ethnic and environmental rights. The 2009 constitution includes articles that favour such an attitude towards these rights, if revenues of extractive activities are used for the common good and economic redistribution. ${ }^{64}$ Consequently, following this reasoning, if class interests define the prioritised politics aimed at the common good and economic redistribution, the ethnic and environmental rights may be sidestepped.

However, the relationships and tensions between class, ethnicity and ecologism are, as stated, more complex. Anthropologist John-Andrew McNeisch emphasises the complexity of Bolivian identity politics and indigeneity. As he argues, a frequent misunderstanding by analysts is found in the simplification and generalisation of the relationship between class and ethnicity. Neither should the TIPNIS conflict be interpreted as such, that is, as a battle between indigenous and environmental activists on the one hand and the developmentalist and class-defined position of the government on the other. Even if these specific interests indeed exist, the realities of ethnic and class-based identification of the indigenous peoples are more complex and in flux. The indigenous communities have adapted to capitalist, consumptionist and developmentalist practices for many decades, which have shaped outcomes regarding collective and individual identities. ${ }^{65}$

It should similarly be emphasised that the grievances of the rural indigenous populations towards the state - both among oppositional and government supporters - generally have more to do with infrastructure, health and education, than with ecological concern or ethnic-cultural rights, as perceived during recent fieldwork in the Amazon (Beni department), as well as in the lowlands of El Chaco (Santa Cruz department). ${ }^{66}$

Rounding off, the extractive dilemma has been characterised by recent years of contentious politics and resource governance in Bolivia. Often these conflicts have been portrayed as choices between ethnic and environmental values and rights on the one hand and - agreeing with McNeisch - economic, developmentalist and class-defined interests and values on the other. The realpolitik is always a question of choices and priorities, and there will always be a certain degree of compromise and sacrifice of specific rights, interests and values.

\section{Concluding remarks}

In this article I have examined the ethnically defined rights in relation to broader and classdefined human rights in the historical context of the extractive development politics of the Evo Morales government. On the one hand, ethnic rights (and identity) were scrutinised in relation to rights/identities defined by class, albeit bearing in mind that these identitarian bases are complexly and intimately intertwined in Bolivian contemporary history. On the other hand, the relative recognition of these rights was inspected from the angle of Bolivian political economy and conditioned by the dilemma of extractive development.

The ethnic identity of the Bolivian indigenous populations is multifaceted and a large segment of these have preferred to identify primarily in class terms, as peasants, although at the same time recognising their ethnic identity. Indigeneity in Bolivia is to a large extent conditioned by the element of class identification, particularly in the central organisations behind the Morales government. Bolivia is an exemplary case in showing that neither identities nor social movements can be seen as static categories. They change with historical and 
social alterations and the relative positions of individuals and collectives in a specific structure. Broadly speaking, ethnic/indigenous identity has gradually been reinforced during the Morales administration and it is possible to speak of this process in terms of decolonisation and a relative dignification of the indigenous peoples.

The incorporation of the indigenous philosophy of Vivir Bien in the constitution and national development policies has reinforced the ethno-ecologist profile of the Morales government, particularly at a global level. Likewise, as has been discussed, the government uses the indigeneity and ethno-ecologist discourses strategically.

It has been argued that in the Bolivian practice, ethnic rights (intertwined with environmental rights) frequently tend to be downgraded in relation to the broader class-defined rights as an outcome of the extractive dilemma. While indigenous rights were decisively reinforced with the constitutional reform of 2009 , these rights clash with the constitutionally recognised rights of the nation state to extract and commercialise natural resources (mainly hydrocarbons and mining) under the banner of redistributive justice, welfare reforms and the common good - class-defined rights. This is a crucial expression of the dilemma of extractive development.

The relative superiority of class-defined rights vis-à-vis ethno-territorial rights is likewise apparent when examining the government's justification of extractive projects and the contentious construction of the highway through the TIPNIS territory. Summing up, on basis of the material examined in this study, it is possible to conclude that ethnic (and environmental) rights are frequently being subordinated to broader class-defined social rights, as a consequence of the dilemma of extractive development.

\section{Acknowledgements}

The author wishes to express gratitude to all colleagues and informants in Bolivia during fieldwork, particularly Elizabeth Huanca, Oscar Vega, Fernando Galindo and Xavier Albó, also the anonymous peer-reviewer of the journal and René Kuppe for inspiring comments.

\section{Funding}

This work was supported by Svenska Forskningsrådet Formas [grant award 2012-1828] as part of the project 'Rights of Nature - Nature of Rights: Neo-constitutionalism and Ethno-ecologist Resistance in Bolivia and Ecuador' for the period 2013-2016.

\section{Note on contributor}

Rickard Lalander is Associate Professor of and holds a PhD in Latin American studies from the University of Helsinki. Currently he works as a researcher and teacher in the Department of Political Science at Stockholm University and the Department of Political and Economic Studies at the University of Helsinki. He has published broadly on democracy, identity politics, social movements and environmental issues in the Andean countries and is author of the books Suicide of the Elephants? Venezuelan Decentralization between Partyarchy and Chavismo (2004) and Retorno de los Runakuna. Cotacachi y Otavalo (2010), and editor and co-author of Venezuelan Politics and Society in Times of Chavismo (2006).

\section{ORCID}

Rickard Lalander (D) http://orcid.org/0000-0002-2581-2588 


\section{Notes}

1. Estado Plurinacional de Bolivia, Constitución Política del Estado (La Paz: Estado Plurinacional de Bolivia, 2009), Preamble.

2. The constitutional reform of Bolivia was strongly influenced by the 1989 ILO (International Labor Organization) Convention 169 on the rights of the indigenous peoples and further inspired by the United Nations Declaration of the Rights of Indigenous Peoples (2007).

3. Henry Veltmeyer, 'Bolivia: Between Voluntarist Developmentalism and Pragmatic Extractivism', in The New Extractivism. A Post-Neoliberal Development Model or Imperialism of the Twenty-First Century? Henry Veltmeyer and James Petras, eds (London and New York: Zed Books, 2014), 80-113, quote at 83.

4. See, for instance, Arturo Escobar, 'Latin America at a Crossroads. Alternative Modernizations, or Post-Development?' Cultural Studies 24, no. 1 (2010): 1-65; Kepa Artaraz, Bolivia. Refounding the Nation (London: Pluto Press, 2012).

5. Estado Plurinacional de Bolivia, Constitución Política del Estado.

6. Nancy G. Postero, Now We Are Citizens. Indigenous Politics in Postmulticultural Bolivia (Stanford, CA: Stanford University Press, 2007); John-Andrew McNeish, 'Extraction, Protest and Indigeneity in Bolivia: The TIPNIS Effect', Latin American and Caribbean Ethnic Studies 8, no. 2 (2013) 221-42; Lorenza Belinda Fontana, 'Indigenous Peoples vs Peasant Unions: Land Conflicts and Rural Movements in Plurinational Bolivia', The Journal of Peasant Studies 41, no. 3 (2014): 297-319.

7. Rickard Lalander, 'Rights of Nature and the Indigenous Peoples in Bolivia and Ecuador: A Straitjacket for Progressive Development Politics?' Iberoamerican Journal of Development Studies 3, no. 2 (2014): 148-72.

8. Irène Belliera and Martin Préaud, 'Emerging Issues in Indigenous Rights: Transformative Effects of the Recognition of Indigenous Peoples', International Journal of Human Rights 16, no. 3 (2012): 474-88.

9. Markus Kröger and Rickard Lalander, 'Ethno-Territorial Rights and the Resource Extraction Boom in Latin America: Do Constitutions Matter?' Third World Quarterly 37, no. 4 (2016): $682-702$.

10. Marc Becker, 'Indigenismo and Indian Movements in Twentieth-Century Ecuador' (paper presented at the Congress of LASA (Latin American Studies Association), Washington, 1995).

11. George Gray Molina, 'Ethnic Politics in Bolivia: "Harmony of Inequalities" 1900-2000' (Working paper, Centre for Research on Inequality, Human Security and Ethnicity/CRISE, University of Oxford, 2007).

12. Ibid., 6 .

13. Leonel Cerruto, Interview, El Alto, 23 November 2015.

14. Xavier Albó, Movimientos y poder indígena en Bolivia, Ecuador y Perú (La Paz: CIPCA, 2009), 36.

15. Pedro Portugal Mollinedo, Internet Interview, 10 February 2016.

16. Deborah Yashar, Contesting Citizenship in Latin America. The Rise of Indigenous Movements and the Postliberal Challenge (Cambridge: Cambridge University Press, 2005), 168-9.

17. Albó, Movimientos y poder indígena, 36-40; Yashar, Contesting Citizenship.

18. Almut Schilling-Vacaflor, 'Prior Consultations in Plurinational Bolivia: Democracy, Rights and Real Life Experiences', Latin American and Caribbean Ethnic Studies 8, no. 2 (2013): 202-20, quote at 207.

19. For instance: Albó, Movimientos y poder indígena, 43-67.

20. See, for instance, Fernando Luis García Yapur, Luis Alberto García Orellana, and Marizol Soliz Romero, 'MAS legalmente, IPSP legítimamente'. Ciudadanía y devenir Estado de los campesinos indigenas en Bolivia (La Paz: PIEB, PNUD, 2014).

21. I choose to use native throughout the text, and not the concepts of 'first peoples' or 'aboriginal' that are sometimes used while translating the Spanish ethnic concept of originarios.

22. See Fontana, 'Indigenous Peoples vs Peasant Unions', 305-7; García Yapur, García Orellana and Soliz Romero, 'MAS legalmente, IPSP legitimamente'.

23. For example, García Yapur, García Orellana and Soliz Romero, 'MAS legalmente, IPSP legítimamente'.

24. Since December 2013, CONAMAQ is divided with one faction supporting the Morales government and the other in opposition. In late 2010 CIDOB divided and presently there are two CIDOBs, one pro-government and the other oppositional. 
25. Fontana, 'Indigenous Peoples vs Peasant Unions', 305-7.

26. Pedro Portugal Mollinedo, Internet Interview, 10 February 2016.

27. Albó, Movimientos y poder indígena, 39.

28. Confederación Sindical Única de Trabajadores Campesinos de Bolivia/CSUTCB, Estatuto Orgánico de la CSUTCB, Santa Cruz, 30 July 2010, http://comisionorganica-csutcb.blogspot. se/2012/09/estatuto-organico-de-la-csutcb-aprovado.html

29. Artaraz, Refounding the Nation, 45.

30. Karin Monasterios, Pablo Stefanoni, and Hervé do Alto, Reinventando la nación en Bolivia: movimientos sociales, Estado y poscolonialidad (La Paz: Plural editores, 2007), 28. However, Choquehuanca was not a militant of the historical Indianismo movement. Rather he was formed through non-governmental organisation (NGO) activism.

31. For instance: Eduardo Gudynas, 'Buen Vivir: Today's Tomorrow', Development 54, no. 4 (2011): 441-7; Kepa Artaraz and Melania Calestani, 'Suma Qamaña in Bolivia. Indigenous Understandings of Well-being and Their Contribution to a Post-Neoliberal Paradigm', Latin American Perspectives 42, no. 5 (2015): 216-33; Rickard Lalander, 'Entre el ecocentrismo y el pragmatismo ambiental: Consideraciones inductivas sobre desarrollo, extractivismo y los derechos de la naturaleza en Bolivia y Ecuador', Revista Chilena de Derecho y Ciencia Política 6, no. 1 (2015): 109-52.

32. Catherine Walsh, 'The Plurinational and Intercultural State: Decolonization and State ReFounding in Ecuador', Kult 6 (2009): 65-84.

33. Schilling-Vacaflor, 'Prior Consultations in Plurinational Bolivia'.

34. Estado Plurinacional de Bolivia, Constitución Política del Estado, Chapter VII; Andrew Canessa, 'Conflict, Claim and Contradiction', Critique of Anthropology 34, no. 2 (2014): $153-73$, quote at 167.

35. Eduardo Gudynas, Extractivismos. Ecología, economía y política de un modo de entender el desarrollo y la Naturaleza (Cochabamba: CLAES and CEDIB, 2015); Lalander, 'Entre el ecocentrismo y el pragmatismo ambiental'.

36. Estado Plurinacional de Bolivia, Ley Marco de la Madre Tierra y Desarrollo Integral para Vivir Bien (La Paz: Asamblea Legislativa del Estado Plurinacional de Bolivia, 2012).

37. Lalander, 'Entre el ecocentrismo y el pragmatismo ambiental', 126-7.

38. Nicole Fabricant, 'Good Living for Whom? Bolivia's Climate Justice Movement and the Limitations of Indigenous Cosmovisions', Latin American and Caribbean Ethnic Studies 8, no. 2 (2013): 160.

39. Shepard Krech Ill, The Ecological Indian: Myth and History (New York: W. W. Norton \& Co., 1999).

40. Astrid Ulloa, The Ecological Native. Indigenous Peoples Movements and Eco-Governmentality in Colombia (New York: Routledge, 2005).

41. Edwin Armata Balcazar and Walter Limache Orellana, Group Interview, La Paz, 18 December 2015.

42. Álvaro García Linera, Geopolítica de la Amazonía. Poder hacendal-patrimonial y acumulación capitalista (La Paz, Vicepresidencia del Estado Plurinacional de Bolivia, 2012), 58-65.

43. See for instance: Fundación Tierra, Marcha indigena por el TIPNIS; McNeish, 'Extraction, Protest and Indigeneity'. The 2011 march was neither the first nor the last march in defence of TIPNIS. In 2012 a similar manifestation was realised, but did not succeed in attracting the participation and media coverage of the 2011 march.

44. Ibid. Quotation in Spanish originally published in Fundación Tierra, Marcha indígena por el TIPNIS. La lucha en defensa de los territorios, Comunicaciones (La Paz: El País S.A. 2012), 56.

45. Página Siete, 'El Vicepresidente descarta carretera por el TIPNIS', 4 January 2014, http://www. paginasiete.bo/nacional/2014/1/4/vicepresidente-descarta-carretera-tipnis-10441.html; Álvaro García Linera, Los desafios del proceso de cambio en Bolivia (Conference at the Centro Cultural de Cooperación Floreal Gorini, Buenos Aires, 27 June 2013), http://www.centrocultural.coop/ videos/la-patria-grande-alvaro-garcia-linera-1-.html

46. Página Siete, 'Bolivia se sumó a la corriente de explotar áreas protegidas', 24 June 2015, http:// www.paginasiete.bo/nacional/2015/6/24/bolivia-sumo-corriente-explotar-areas-protegidas60974.html

47. Evo Morales Ayma, Decreto Supremo No 2366, Presidential Decree, Estado Plurinacional de Bolivia, La Paz, 2015. 
48. El Día, 'Gobierno busca anular la "intangibilidad” del Tipnis', 28 June 2015, http://eldia.com. bo/index.php?cat $=1 \&$ pla $=3 \&$ id_articulo $=174956$

49. David Hill, 'Bolivia Opens Up National Parks to Oil and Gas Firms', The Guardian, 5 June 2015,http://www.theguardian.com/environment/andes-to-the-amazon/2015/jun/05/bolivianational-parks-oil-gas

50. Observatorio de Industrias Extractivas y Derechos Colectivos/OIEDC, 'Evo: En la consulta previa se pierde mucho tiempo', 13 July 2015, http://oiedc.blogspot.se/2015/07/evo-en-laconsulta-previa-se-pierde.html

51. Página Siete, 'Indígenas de 50 pueblos dieron aval para tareas de exploración', 3 October 2015, http://www.la-razon.com/economia/Gobierno-indigenas-pueblos-dieron-aval-tareasexploracion_0_2355964414.html

52. René Orellana Halkyer, Interview, La Paz, 31 January 2014. Orellana holds a PhD in sociology and was earlier the main spokesperson of Bolivia in climate summits. He was also co-author of the Law of Mother Earth.

53. Evo Morales Ayma, Discurso presidencial 639 (Ministerio de Comunicación, Estado Plurinacional de Bolivia, La Paz, 7 August 2015, http://www.comunicacion.gob.bo/sites/default/files/ media/discursos/Discurso\%20Presidencial\%2007-08-15.pdf

54. Rebecca Hollender, 'Capitalizing on Public Discourse in Bolivia - Evo Morales and Twentyfirst Century Capitalism', Consilience: The Journal of Sustainable Development 15, no. 1 (2016): 50-76.

55. Schilling-Vacaflor, 'Prior Consultations in Plurinational Bolivia', 207.

56. Canessa, 'Conflict, Claim and Contradiction'.

57. McNeish, 'Extraction, Protest and Indigeneity'; Fabricant, 'Good Living for Whom?'.

58. Interview, Rurrenabaque, 16 November 2015.

59. Cerruto, Interview, El Alto, 23 November 2015.

60. Damian Condori, Interview, Sucre, 10 January 2011.

61. Anders Burman, "Now We Are Indígenas": Hegemony and Indigeneity in the Bolivian Andes', Latin American and Caribbean Ethnic Studies 9, no. 3 (2014): 247-71.

62. Author's analysis of public discourses and observations during fieldwork (2010-2015). See also: Nancy Postero, 'Protecting Mother Earth in Bolivia: Discourse and Deeds in the Morales Administration', in Amazonía. Environment and the Law in Amazonia: A Plurilateral Encounter, James M. Cooper and Christine Hunefeldt, eds (Brighton: Sussex Academic Press, 2013), 78-93; Fabricant, 'Good Living for Whom?'

63. Jorge Viaña Uzieda, Interview, La Paz, 20 January 2014.

64. Lalander, 'Entre el ecocentrismo y el pragmatismo ambiental'.

65. McNeish, 'Extraction, Protest and Indegeneity', 238.

66. Author's observation and interviews, November-December 2015. 